\title{
РЕЦЕНЗІЯ
}

DOI: 10.31866/2616-759x.2.2.2019.187297

\section{Валерій Пацунов}

заслужений діяч мистецтв України, професор;

e-mail:v.patsunov@gmail.com; ORCID: 0000-0002-9757-3651

Науково-дослідний інститут Київського національного університету культури і мистецтв

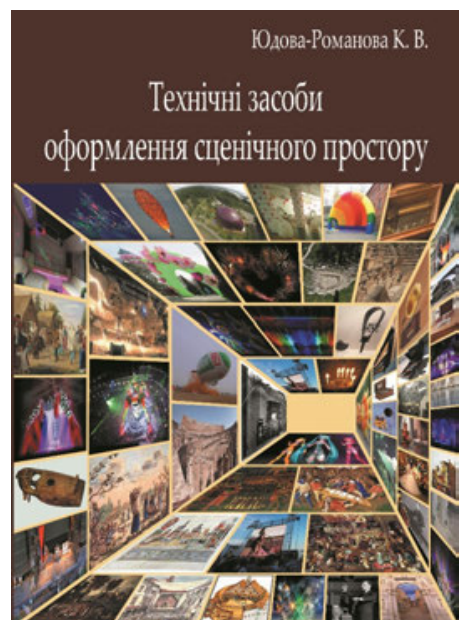

Юдова-Романова, К.В., 2017.

Технічні засоби оформлення сценічного простору. Київ:

Видавничий центр КНУКіМ.

ludova-Romanova, K.V., 2017.

Tekhnichni zasoby oformlennia stsenichnoho prostoru [Technical means of designing stage space].

Kyiv: Publishing Center KNUCiM.

Юдова-Романова К. В. Технічні засоби оформлення сценічного простору : навч. посіб. Київ : Вид. центр КНУКіМ, 2017. 314 с.

Навчальний посібник К. В. Юдової-Романової «Технічні засоби оформлення сценічного простору» присвячено складній та маловисвітленій у науково-навчальній літературі проблемі місця та ролі технічних засобів оформлення сценічного простору. Сучасний стан розвитку сценічного мистецтва (театрального, естрадного, циркового, хореографічного та ін.) і шоу-бізнесу тісно пов'язаний з розвитком науково-технічного прогресу та рівнем застосування в мистецькому процесі технічних засобів оформлення сценічного простору. Останнім часом у мистецтві все більшого значення набуває видовищна складова, зокрема високохудожні театральні та театралізовані дійства створюються завдяки широкій імплементації в них технічної складової - мультимедійних технологій, піротехнічних засобів, аудіо- та відеотехніки тощо. Лінійне оволодіння комплексними та новітніми знаннями з цієї тематики конче необхідне випускникам спеціальності «Сценічне мистецтво»- майбутнім режисерам, сценографам, організаторам театральної справи та шоу-бізнесу.

Навчальний посібник К. В. Юдової-Романової «Технічні засоби оформлення сценічного простору» докладно та систематизовано подає таку інформацію - від 
давніх театралізованих обрядів до сучасних театралізованих та естрадних шоу з використанням надсучасного технічного обладнання. Посібник стане в пригоді як студентам, майбутнім митцям сцени, так і кожному викладачеві, який бажає удосконалити свій професійний рівень.

Посібник складається з двох розділів, кожен з яких під різним кутом зору висвітлює питання технічного арсеналу сценічного простору. Перший розділ «Основні етапи розвитку сценічного простору та його художньо-технічного оснащення» присвячено історичному аспекту, другий розділ «Сучасні технічні засоби оформлення театралізованих дійств» - сучасному стану технічного озброєння сцени. Такий системно-лінійний підхід можна вважати цілком виправданим і логічним для ефективного засвоєння знань користувачем посібника. Так, саме користувачем, а не лише читачем, адже багатий ілюстративний матеріал спонукає до уважного його перегляду, а посилання на інтернет-сайти виробників технічних засобів сприяє можливостям розширеного пошуку інформації.

У першому розділі «Основні етапи розвитку сценічного простору та його художньотехнічного оснащення» авторка поставила за мету дати короткий екскурс в історію розвитку технічного забезпечення сценічних дійств засобами декораційнохудожнього, музичного оформлення та архітектури сценічних майданчиків. Матеріал висвітлено в шести темах: «Архітектура та засоби оформлення театралізованих дійств і вистав у Стародавньому світі», «Технічний арсенал театралізованих дійств Київської Русі та Середньовічної Європи», «Архітектура та театрально-декораційне мистецтво епохи Відродження та Просвітництва», «Піротехнічне мистецтво в оформленні вуличних видовищ у Російській імперії», «Етапи становлення та розвитку звукозаписувальної та звуковідтворювальної техніки», «Світлотехніка сценічного простору».

Варто зауважити, що незначне місце в цьому огляді займають питання театральної архітектури як такої та відсутність інформації про технічне забезпечення циркового мистецтва та архітектури цирків. Але такий факт цілком може бути виправданий форматом видання (це навчальний посібник, а не підручник), що передбачає можливість оминути викладення окремих аспектів проблеми.

Другий розділ «Сучасні технічні засоби оформлення театралізованих дійств» структуровано дев'ятьма темами: «Модульні сценічні конструкції і підлогове покриття», «Пневматичні конструкції і сценічний простір», «Візуальні засоби оформлення театралізованих заходів», «Піротехнічні засоби оформлення шоу-програм», «Генератори спеціальних ефектів», «Світлотехніка та лазерна техніка», «Мультимедійні технології», «Системи звукового забезпечення», «Електронні музичні інструменти», в яких викладено характеристику сьогоднішнього стану технічного арсеналу, що застосовується постановниками під час організації та проведення театральних вистав і театралізованих дійств, проаналізовано перспективні напрями мистецьких пошуків у царині застосування технічних новітніх технологій та сучасної сценічної техніки.

Надання можливості контролю засвоєння знань через систему тестових завдань з ключами, які наведено до кожної з тем розділів, максимально реалізує самонавчальну функцію посібника як засобу навчання та забезпечує надійне 
управління самостійною роботою студентів з метою засвоєння теоретичного та практичного матеріалу курсу.

Ознайомлення із запропонованою системою викладення знань свідчить, що авторка провела велику за обсягом роботу щодо добору, систематизації, структуризації та оптимізації інформації з теорії, історії та практики сценічного мистецтва та місця і ролі в ньому науково-технічного прогресу. Виклад подано на високому науково-теоретичному рівні із залученням основоположних категорій методики.

Безперечно методологічно корисним для засвоєння поданого матеріалу є запропонований авторкою термінологічний словник. Він у стислій формі характеризує основні поняття і терміни, що використовуються в основному (лекційному) матеріалі.

До переваг навчального посібника можна зарахувати також наявність великого списку рекомендованих джерел - понад 500 позицій. У ньому розміщено не тільки україномовні та російськомовні публікації, а й франко-, англо- та німецькомовні, що свідчить про широту пошуку й інформативну насиченість поданого матеріалу. Тут буде доречною пропозиція структурувати за темами список рекомендованих джерел, що полегшило б користування ним та сприяло б підвищенню культури роботи студентів із матеріалом у процесі його засвоєння.

У цілому навчальний посібник К. В. Юдової-Романової засвідчує глибоке осмислення курсу знань з технічного забезпечення сценічного простору та заслуговує на позитивну оцінку як оригінальна творча робота, що базується на органічному поєднанні теоретично-історичного підходу з практикою існування сучасного сценічного мистецтва в Україні та за їі межами. Форма викладу матеріалу відповідає вимогам як стаціонарної, так і заочної (дистанційної) навчальної діяльності.

Хотілося б зазначити, що ця праця стане в пригоді під час підготовки режисерів драматичного театру, режисерів естради та масових свят, професійних режисерів театрів та шоу-бізнесу, організаторів культурно-дозвіллєвої діяльності, менеджерів, організаторів театральної справи, художників-сценографів і загалом широкого спектру фахівців у галузі сценічного мистецтва та шоу-бізнесу. Представлена в посібнику інформація $€$ корисною для широкого кола шанувальників сценічного мистецтва як така, що може стати підґрунтям для їхньої самоосвіти у вивченні технічних засобів оформлення сценічного простору, а також теорії та практики сценічного мистецтва.

На нашу думку, рецензований навчальний посібник К. В. Юдової-Романової «Технічні засоби оформлення сценічного простору» $€$ беззаперечним свідченням високої теоретико-методологічної підготовки автора з проблем сценічного мистецтва та унікальним зразком видання, в якому акцентовано увагу на технічних засобах оформлення сценічного простору. Робота заслуговує позитивної оцінки, оскільки виконана на високому фаховому мистецтвознавчому та педагогічнометодичному рівні. 